DOE/PC/90156--2

DE93 000597

DEVELOPMENT AND TESTING OF A COMMERCIAL-SCALE COAL-FIRED COMBUSTION SYSTEM - PHASE III

Quarterly Technical Progress Report No. 2 Report Period: January 1, 1991 to March 31, 1991

By

A.F. Litka and R.W. Breault

July 1991

Work Performed Under Contract No. DE-AC22-90PC90156

Prepared for

PETC Project Manager: Mr. Douglas Gyorke

Pittsburgh Energy Technology Center

U.S. Department of Energy

P.O. Box 10940

Pittsburgh, Pennsylvania 15236-0940

\footnotetext{
Prepared by

Tecogen Inc.

45 First Avenue

P.O. Box 9046
}

Waltham, Massachusetts 02254-9046

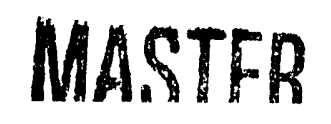


TABLE OF CONTENTS

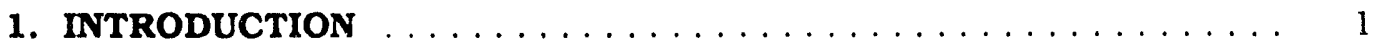

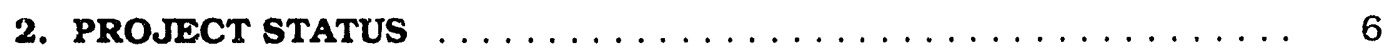

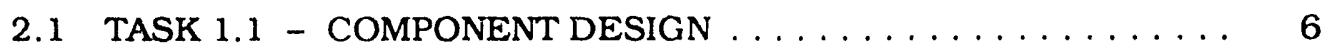

2.2 TASK 1.2 - COMPONENT FABRICATION $\ldots \ldots \ldots \ldots \ldots \ldots 18$

3. Planned activities $\ldots \ldots \ldots \ldots \ldots \ldots \ldots \ldots \ldots \ldots \ldots \ldots$

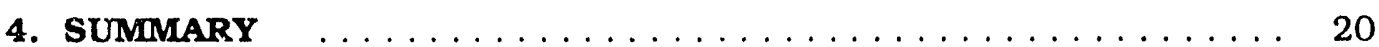




\section{LIST OF ILUSTRATIONS}

1.l Work Breakdown Structure for Entire Project . . . . . . . . . . . 4

2.1 Combustor/Transition Chamber Configuration ......... 7

2.2 Combustor Outlet Temperature versus Insulation Thickness ... 8

2.3 Boller Inlet Temperature versus Combustor Outlet Temperature and Insulation Thickness $\ldots \ldots \ldots \ldots \ldots \ldots$

2.4 York-Shipley Fire-Tube Heat-Recovery Boller Configuration $\ldots . .10$

2.5 Hot Water Flow Diagram . . . . . . . . . . . . . . 14

2.6 Delavan Delta Swirl-Air Atomizing Nozzle . . . . . . . . . . . . . 15

$2.7 \quad$ Bete XA Series External Mix Flat Fan Nozzle . . . . . . . . . . . 15

2.8 Slurry Injection Configurations $\ldots \ldots \ldots \ldots \ldots$

2.9 Process Control and Instrumentation Diagram $\ldots \ldots \ldots \ldots 17$ 


\section{LIST OF TABLES}

1.1 Performance Goals $\ldots \ldots \ldots \ldots \ldots \ldots \ldots \ldots \ldots$

2.1 Boiler Selection Summary . . . . . . . . . . . . 11

$2.2 \quad$ Performance Data for $400-\mathrm{ft}^{2}$ Boiler $\ldots \ldots \ldots \ldots \ldots \ldots \ldots$ 


\section{INTRODUCTION}

Coal is the most plentiful energy resource in the United States, and in 1987 it provided approximately one third of the quads of total energy consumed in the United States. Its use, however, has been largely restricted to utility power generation since World War II for environmental and economic reasons.

Within the commercial sector, oll and natural gas are the predominant fuels used to meet the space-heating needs of schools, office bulldings, apartment complexes, and other similar structures. In general, these bulldings require firing rates of 1 to 10 million $\mathrm{Btu} / \mathrm{hr}$. The objective of this program is to demonstrate the technical and economic viability of a coal-fired combustion system for this sector.

The development program includes all aspects of the process, from fuel selection and preparation to pollution control and waste disposal. In attempting to restore coal to small users such as residential and commercial space heating, it is important to recognize that fuel form is an important consideration because of its impact on handling and emissions. Ease of handling is an important criterion at the small sizes since complex equipment will add greatly to the overall system costs. Furthermore, manpower is not avallable to perform manual functions or keep complex equipment workdng. Emission levels, if not currently regulated, can be expected to be regulated at low levels in the future. The levels considered acceptable will be reduced over time, following the current environmental trends. Preparation and use of a coal-water slurry fuel can aid in meeting these criteria. Coal-water slurry eliminates the need to use dry pulverized coal with its attendant handling and dusting problems as well as its explosive potential. In addition, coalwater slurry is amenable to coal washing since coal cleaning technologies are generally water-based processes requiring fine grinding of the coal. For these reasons, the prograrn objective will be met through the development of a coal-water slurry fired system.

Although the coal-water slurry fuel in commercial practice will be manufactured by coal companies or fuel suppliers at regicnal facillties and transported to the user much as is done today with oll, the program includes the construction of a slurry production facility. In this way, all aspects of the fuel's use - from coal selection to combustion properties - can be evaluated and an economic evaluation of the process can be carried out.

The commercial-scale coal-water slurry (CWS)-fired space heating system will be a scale-up of a CWS-fired residential warm-air heating system developed by Tecogen under contract to the Department of Energy. Pittsburgh Energy Technology Center. This system included a patented nonslagging combustor known as IRIS, for Inertial Reactor with Internal Separation. This combustion technology, which 
has demonstrated high combustion efficlency using CWS fuels at input rates of $100,000 \mathrm{Btu} / \mathrm{hr}$, will be scaled to operate at 2 to 5 million Btu/hr. Along with the necessary fuel storage and delivery, heat recovery, and control equipment, the system will include pollution control devices to meet targeted values of $\mathrm{NO}_{\mathrm{x}}, \mathrm{SO}_{2}$, and particulate emissions. In general, the system will be designed to match the rellability, safety, turndown, and ignition performance of gas or oll-fired systems. Table 1.1 summarizes the performance goals of the system.

The successful development and future marketability of the heating system requires a strong, dedicated team with expertise in a broad range of areas including coal-water slurry preparation, coal combustion, pollution control, component manufacture, and systems integration. Such a team has been assembled and includes the following organizations: Tecogen, Donlee Technologies, AMAX Coal, and Southern Illinois University.

Tecogen is the prime contractor and is responsible for overall program management, combustor development, and integration of the subsystem components and installation of the system at the field test site. AMAX has extensive experience in coal-water slurry preparation and serves as the principal coal supplier. Donlee Technologies is responsible for the boller/heat exchanger design and manufacture. Donlee has over 70 years' experience in the commercial boiler business and is a potential commercializer of the technology. Southern Illinois University is the host for the field test portion of the program. The heating system will provide space heating at the SIU Coal Research Center.

The development program has been divided into 3 stages covering a time span of 39 months. During the first stage, which covers 14 months, the program will focus on component development. The second stage, which covers a 10-month period, will focus on proof-of-concept testing. The final stage covers a 15-month period and will focus on testing all the components as an integrated system in an actual installation. Figure 1.1 gives the work breakdown structure for the program.

This report documents the work carried out in the second quarter of the program. Activities focused on the detalled design of the major system components.

During the first quarter, work concentrated on the definition of the overall system configuration and the determination of the key parameters to be considered in the combustor design. A preliminary heat balance was developed to define the overall process and to size system components and piping. Coal properties were evaluated and predictions made for the CWS properties capable of being achieved with the selected coals. 
TABLE 1.1

\section{PERFORMANCE GOALS}

- Thermal Input

- Thermal Efficlency

- Combustion Efficiency

- Emissions

- Turndown

- Ignition

- Rellabllity/Safety

- Ash Removal

- RoutIne Malntenance

- Servlce Llfe
- 4 million Btu/hr

$->80 \%$

- $>99 \%$

- $1.2 \mathrm{lb} \mathrm{SO} \mathrm{S}_{2} / \mathrm{MMBtu}$ $0.3 \mathrm{lb} \mathrm{NO}_{x} / \mathrm{MMBtu}$ 0.03 ib Part./MMBtu

- 3:1

- Fully automatic startup with system purge and ignition verification

- Comparable to oll-fired commerclal bollers

- Dust free and automatic or seml-automatlc

- Less than one manhour per day and an additional two manhours per week

$->20$ years 


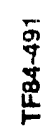
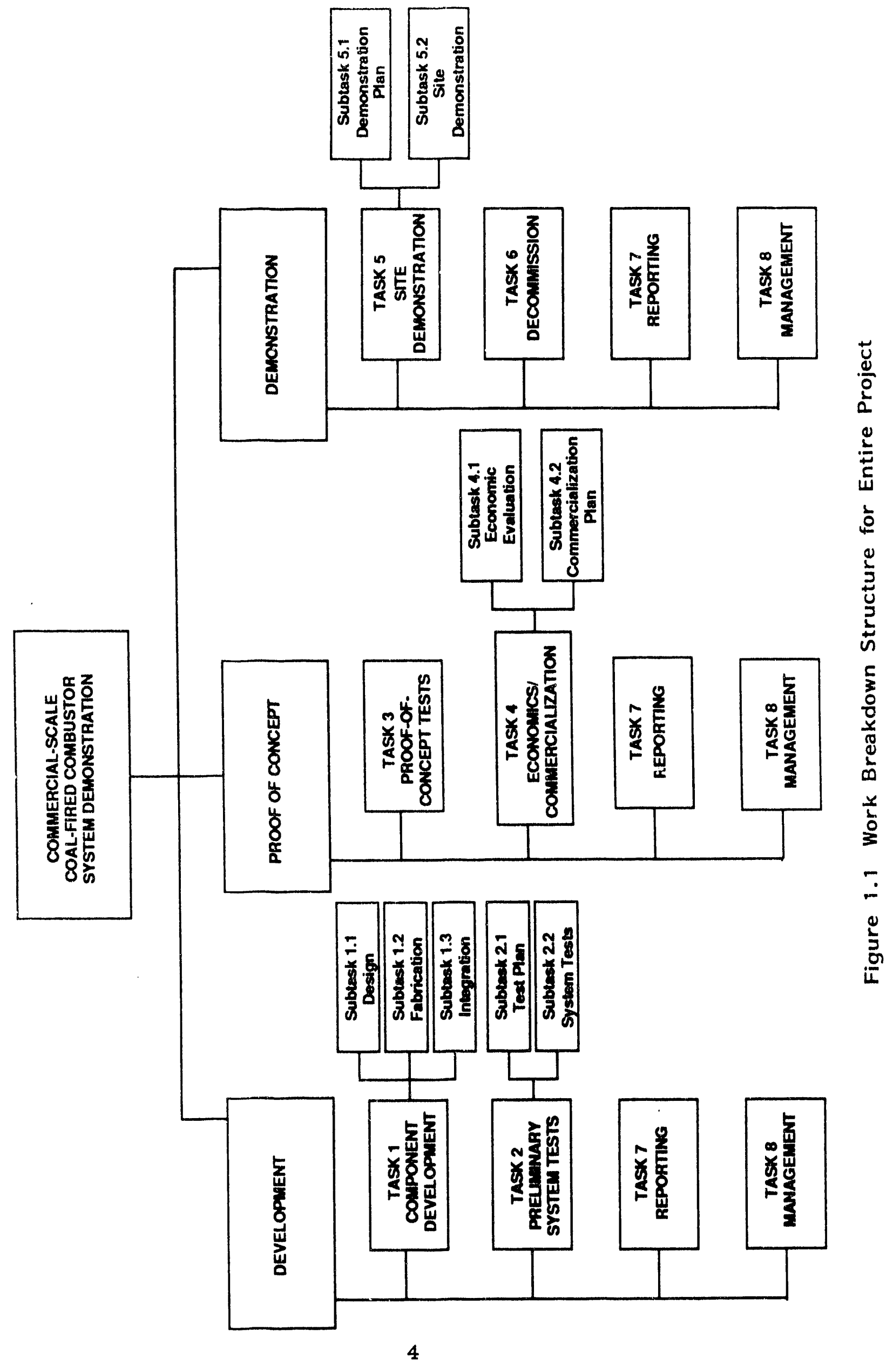

C

c

c 
Combustor scaling laws were developed to allow for an extension of the data base that has been established with the residential combustor and to provide guidelines for the scale-up of this combustor technology to larger sizes. In particular, particle separation, reaction rate kinetics, pressure drop, and residence times were evaluated. 


\section{PROJECT STATUS}

\subsection{TASK 1.1 - COMPONENT DESIGN}

\section{Combustor}

Based on the combustor scaling parameters developed during the prevlous reporting period, a nominal 24-inch-diameter combustor has been selected for the commercial system. This combustor diameter closely matches the diameter determined through straight geometric scallng with equal heat release $r c$ tes, and provides comparable particle retention with acceptable pressure drop and gas velocities. A sketch showing the key combustor dimensions is shown in Figure 2.1; detalled design of the combustor is under way. The combustor will be a doublejacketed water-cooled unit with a refractory liner. A graph of the predicted combustor outlet temperature versus refractory wall thickness is given in Figure 2.2.

The combustor will be connected to a transition chamber that will provide the connection to the boiler as well as collect large ash agglomerates. The transition box will also be a double-jacketed water-cooled unit with a refractory liner. The outlet temperature from the transition box (boller inlet temperature) is plotted versus combustor outlet temperature for various refractory thicknesses in Figure 2.3. Based on these heat loss predictions, the combustor will be designed with a two-inch refractory thickness and the transition box will have a three-inch thickness. This combination will provide a boller inlet temperature of between 2200 and $2300^{\circ} \mathrm{F}$.

\section{Boiler}

A York-Shipley fire-tube heat-recovery boiler will be utilized. A schematic showing the boller configuration is given in Figure 2.4. This three-pass boiler configuration has been utllized on various "dirty" gas applications. In particular, York-Shipley has provided over 50 units for operation with fluidized bed combustors burning wood, coal, and other alternative fuels.

Boller performance data were generated for three standard boiler sizes $\left(400,500\right.$, and $\left.625 \mathrm{ft}^{2}\right)$, at the predicted flue gas flow leaving the combustor. The initial boller selection was based on a boller inlet temperature of $2300^{\circ} \mathrm{F}$. A summary of this evaluation is given in Table 2.1. The $400-\mathrm{ft}^{2}$ boller, which has a smaller drum diameter than the $500 \mathrm{ft}^{2}$ and $625 \mathrm{ft}^{2}$ models $(4.5 \mathrm{ft}$ versus $5.5 \mathrm{ft}$ ) and correspondingly lower tube free flow area and higher gas velocities, results in higher overall heat recovery. The velocities and pressure drops are considered acceptable.

A complete mapping was made of the $400-\mathrm{ft}^{2}$ boiler performance at full, twothirds, and one-third thermal input and for different boller operating conditions $\left(50 \mathrm{psig}, 15 \mathrm{psig}\right.$, and $180^{\circ} \mathrm{F}$ hot water), and the results are summarized in Table 2.2. Since combustor exit temperature at this time can only be estimated 


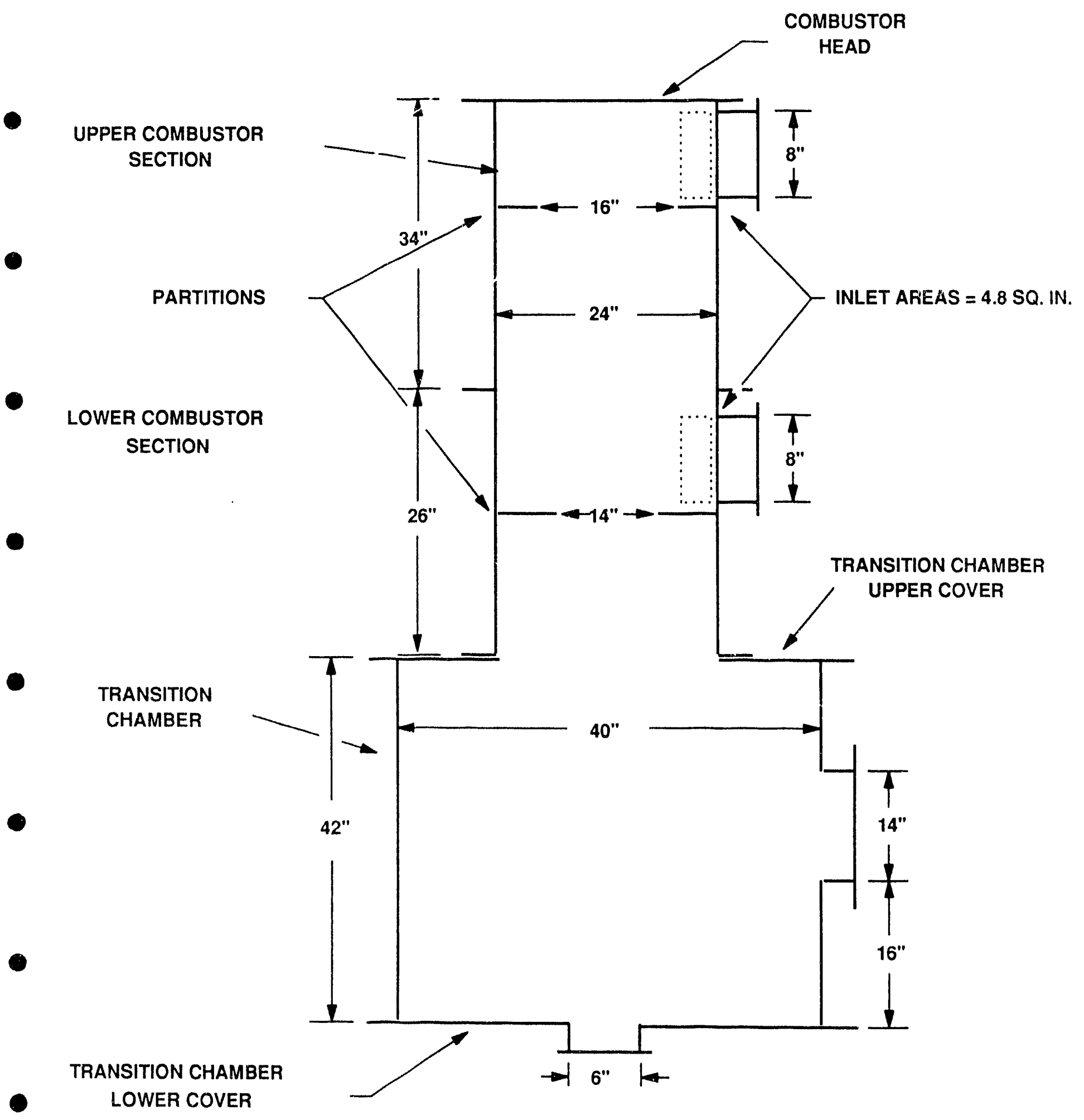

Figure 2.1 Combustor/Transition Chamber Configuration 


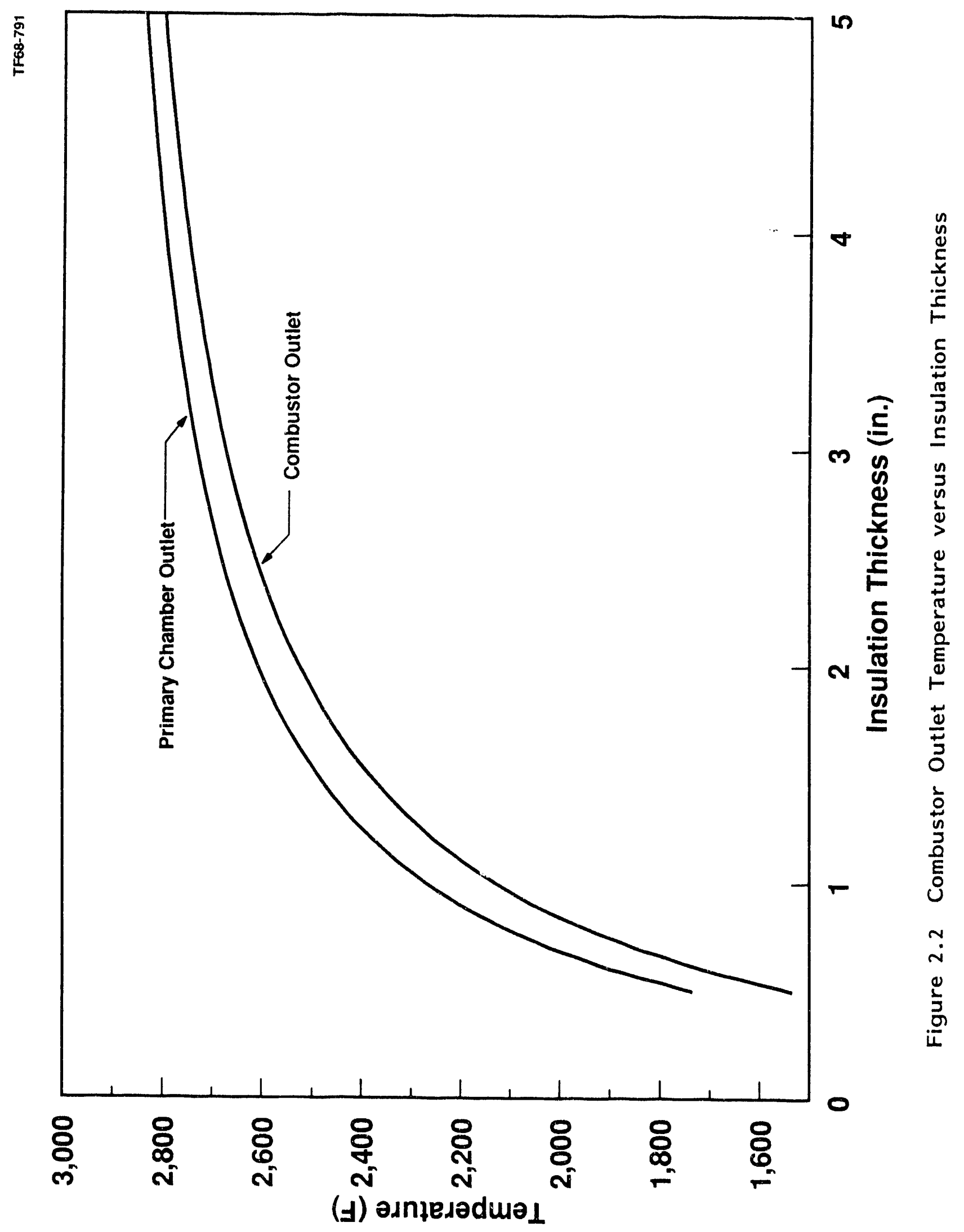




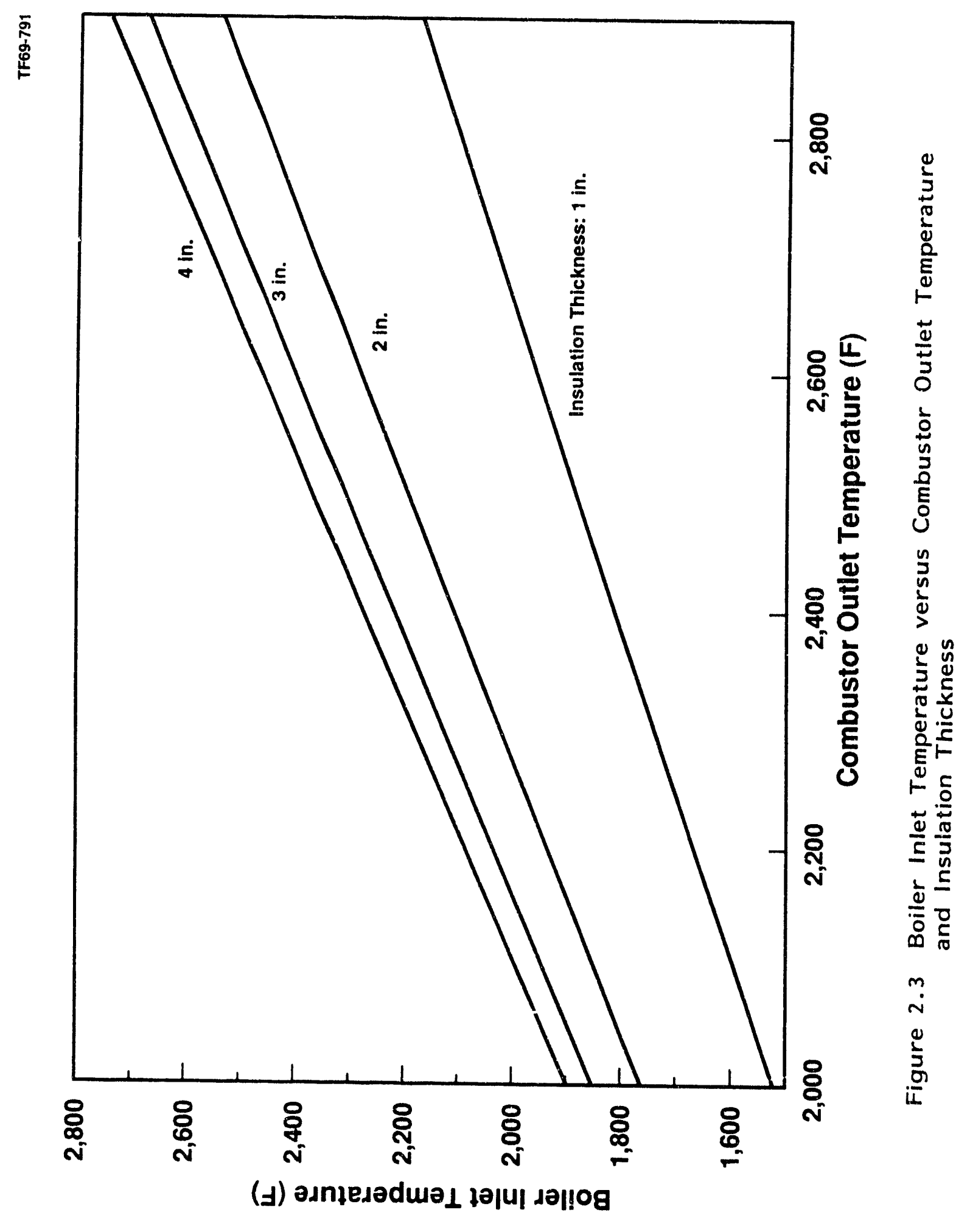




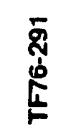

$\begin{array}{r}5 \\ 5 \\ 5 \\ 0 \\ \text { 岁 } \\ \hline\end{array}$
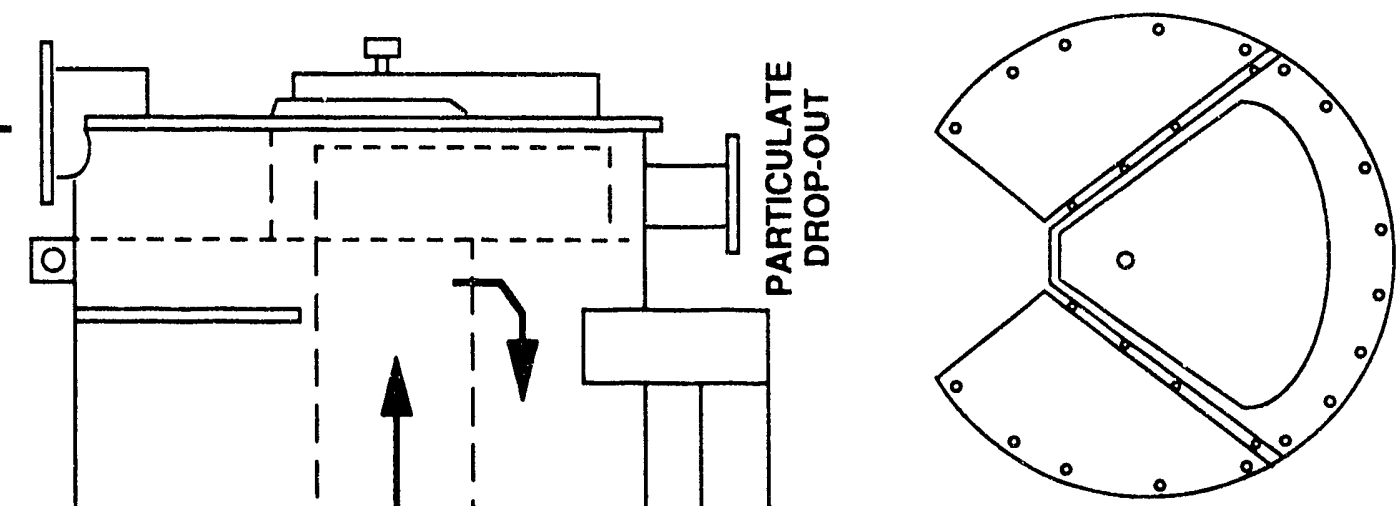

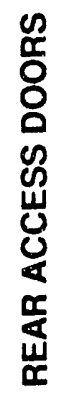

نَ

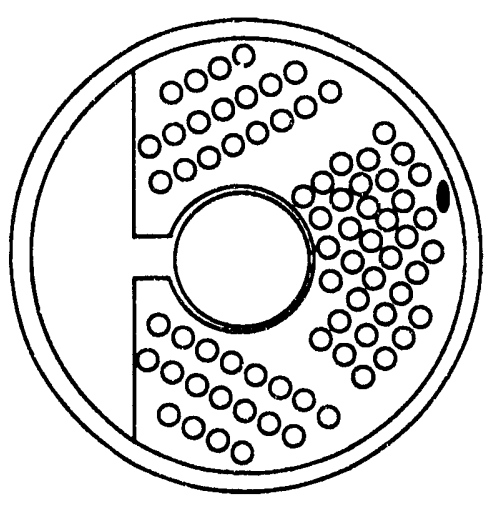

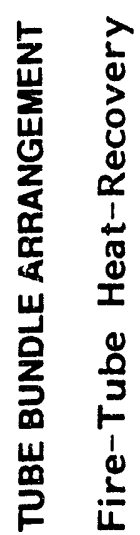
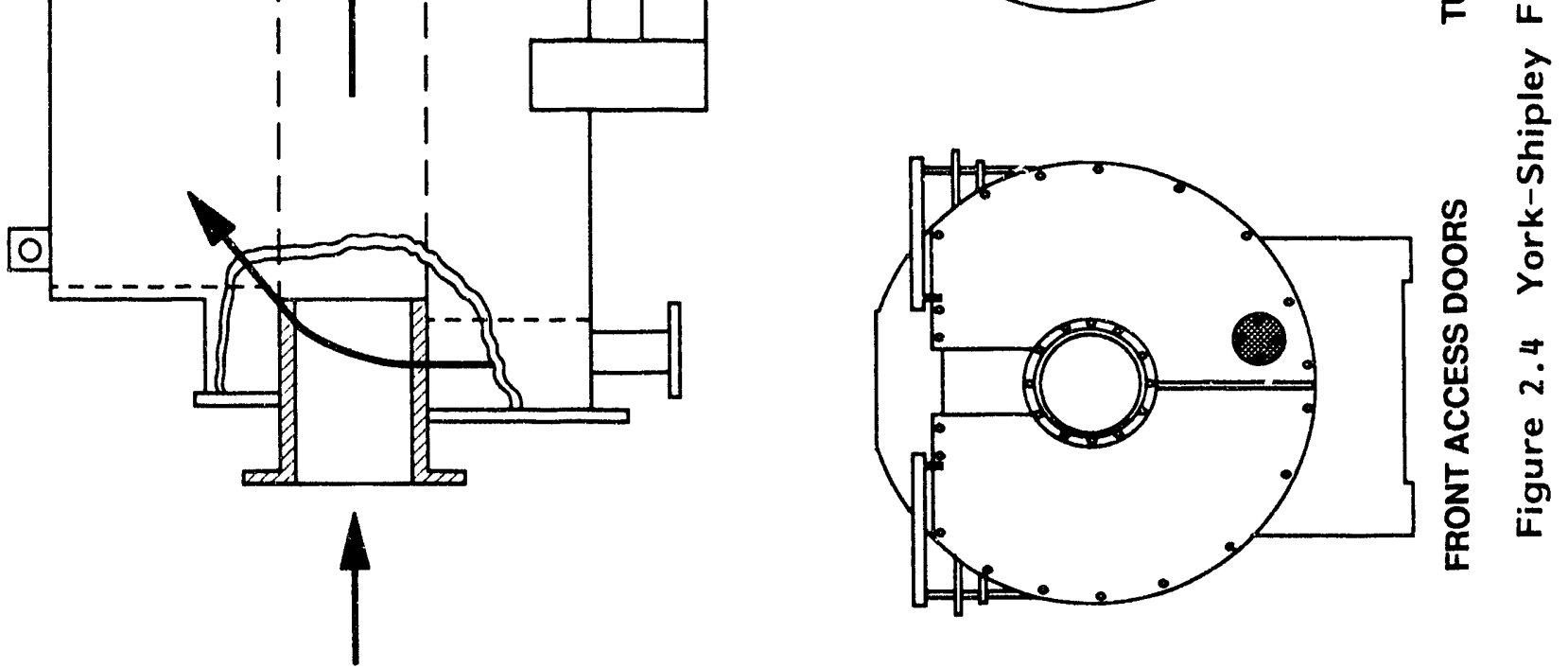

舟峞 
TABLE 2.1

BOILER SELECTION SUMMARY

\begin{tabular}{|l|c|c|c|}
\hline \multicolumn{1}{|c|}{ Boiler Size } & $400 \mathrm{ft}^{2}$ & $500 \mathrm{ft}^{2}$ & $625 \mathrm{ft}^{2}$ \\
\hline Flue Gas Inlet Temp, ${ }^{\circ} \mathrm{F}$ & 2300 & 2300 & 2300 \\
\hline 1st Pass Outlet Temp, $^{\circ} \mathrm{F}$ & 2011 & 2054 & 2004 \\
\hline 2nd Pass Outlet Temp, ${ }^{\circ} \mathrm{F}$ & 750 & 830 & 693 \\
\hline 3rd Pass Outlet Temp, $^{\circ} \mathrm{F}$ & 443 & 494 & 414 \\
\hline 1st Pass Velocity, $\mathrm{ft} / \mathrm{sec}$ & 36.8 & 25.6 & 25.6 \\
\hline 2nd Pass Velocity, $\mathrm{ft} / \mathrm{sec}$ & 87.5 & 52.5 & 51.4 \\
\hline 3rd Pass Velocity, $\mathrm{ft} / \mathrm{sec}$ & 58.0 & 52.5 & 51.4 \\
\hline Pressure Drop, in. wc & 4.3 & 3.8 & 3.8 \\
\hline
\end{tabular}


$\frac{5}{\frac{1}{1}}$

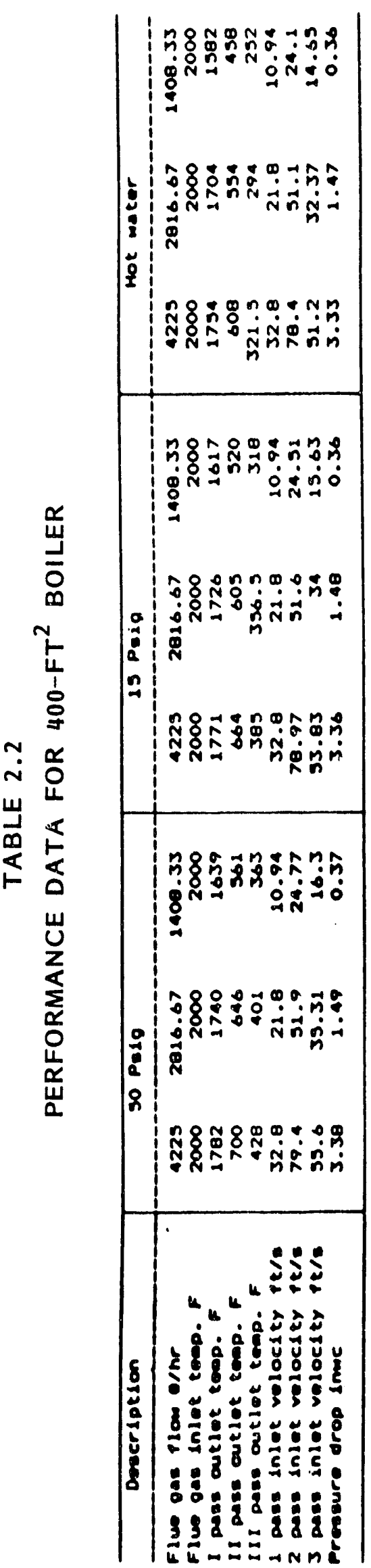

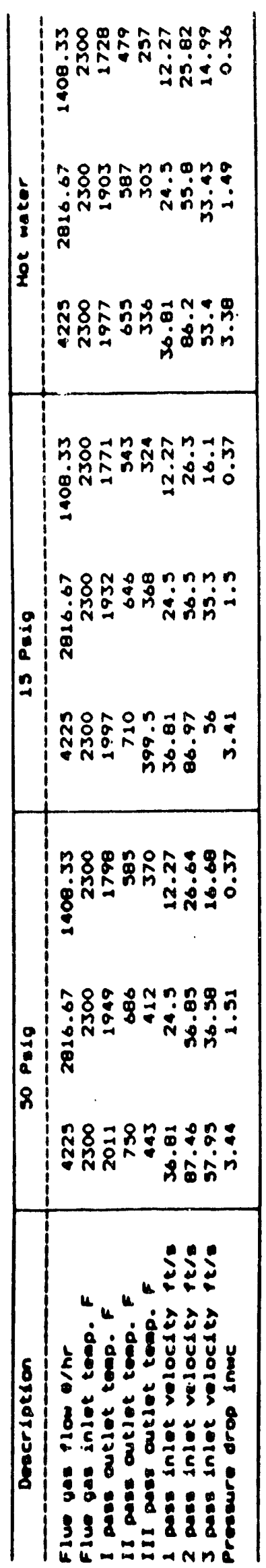

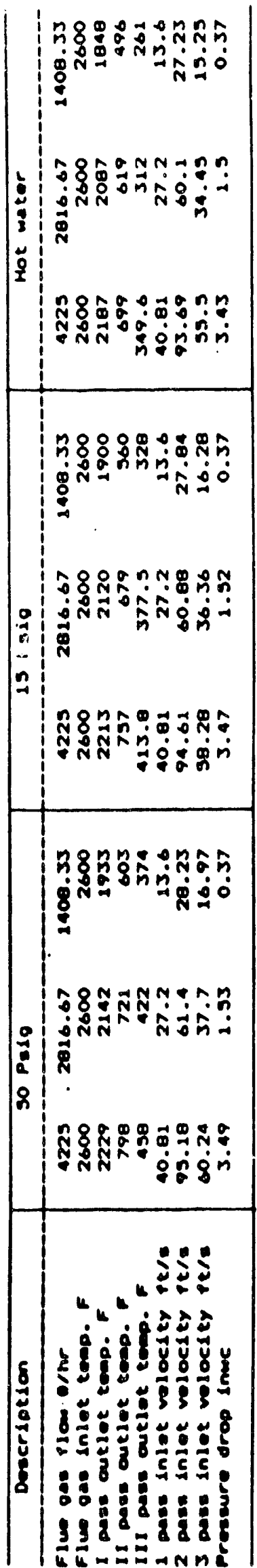


based on combustor performance scaling and heat transfer analysis, performance data were generated for a range of inlet temperatures $\left(2000,2300\right.$, and $2600^{\circ} \mathrm{F}$ ). For all cases, the $400-\mathrm{ft}^{2}$ boller provides sufficient heat extraction to meet the overall system thermal efficiency goal of 80 percent.

A hot-water heating system has icen selected for the demonstration program. Figure 2.5 gives a schematic of the system. As shown. boller water will be used for cooling the combustor and will be returned to the boiler at an elevated temperature. To prevent steam generation, the system will be operated under a pressure of approximately 10 psig through the use of an expansion tank and static leg.

\section{Slurry Atomizers}

A slurry test loop was set up to assess the performance of two commercially available atomizers. Figures 2.6 and 2.7 illustrate the two atomizers. The first is a Delavan Delta Swirl-Air Nozzle and the second is a Bete XA Series External Mix Flat Fan Air Atomizing Nozzle. Both nozzles achieved good atomization of the slurry. The Delavan nozzle produced a hollow cone with an included angle of approximately 90 degrees, and the Bete nozzle produced a flat fan with an included angle of approximately 50 degrees. The spray pattern for the Delavan nozzle is suited for downward firing, and the Bete nozzle is suited for side wall or tangential firing, as tllustrated in Figure 2.8 .

\section{Process Controls}

A control strategy has been developed for the system. The control system will be made up of discrete single loop controllers with a programmable sequencer for overall system cont rol and ladder logic sequencing. A schematic of the process control and instrumentation is given in Figure 2.9. Following is a list of the control system elements:

$\begin{array}{cc}\begin{array}{c}\text { Independent } \\ \text { Variable }\end{array} & \begin{array}{c}\text { Manipulated } \\ \text { Variable }\end{array} \\ \begin{array}{c}\text { Boiler Water Temp. } \\ \text { (variable thermal input) }\end{array} & \text { Fuel Flow } \\ \begin{array}{c}\text { Thermal Input } \\ \text { (fixed thermal input) }\end{array} & \text { Fuel Flow } \\ \begin{array}{c}\text { Boiler Water Temperature } \\ \text { (fixed thermal input) }\end{array} & \text { Thermal Load } \\ \text { Boiler Water Level } & \text { Makeup Water } \\ \text { Draft Pressure } & \text { ID Fan Damper } \\ \text { Baghouse Pressure Drop } & \begin{array}{c}\text { Pulse Air } \\ \text { Frequency }\end{array}\end{array}$




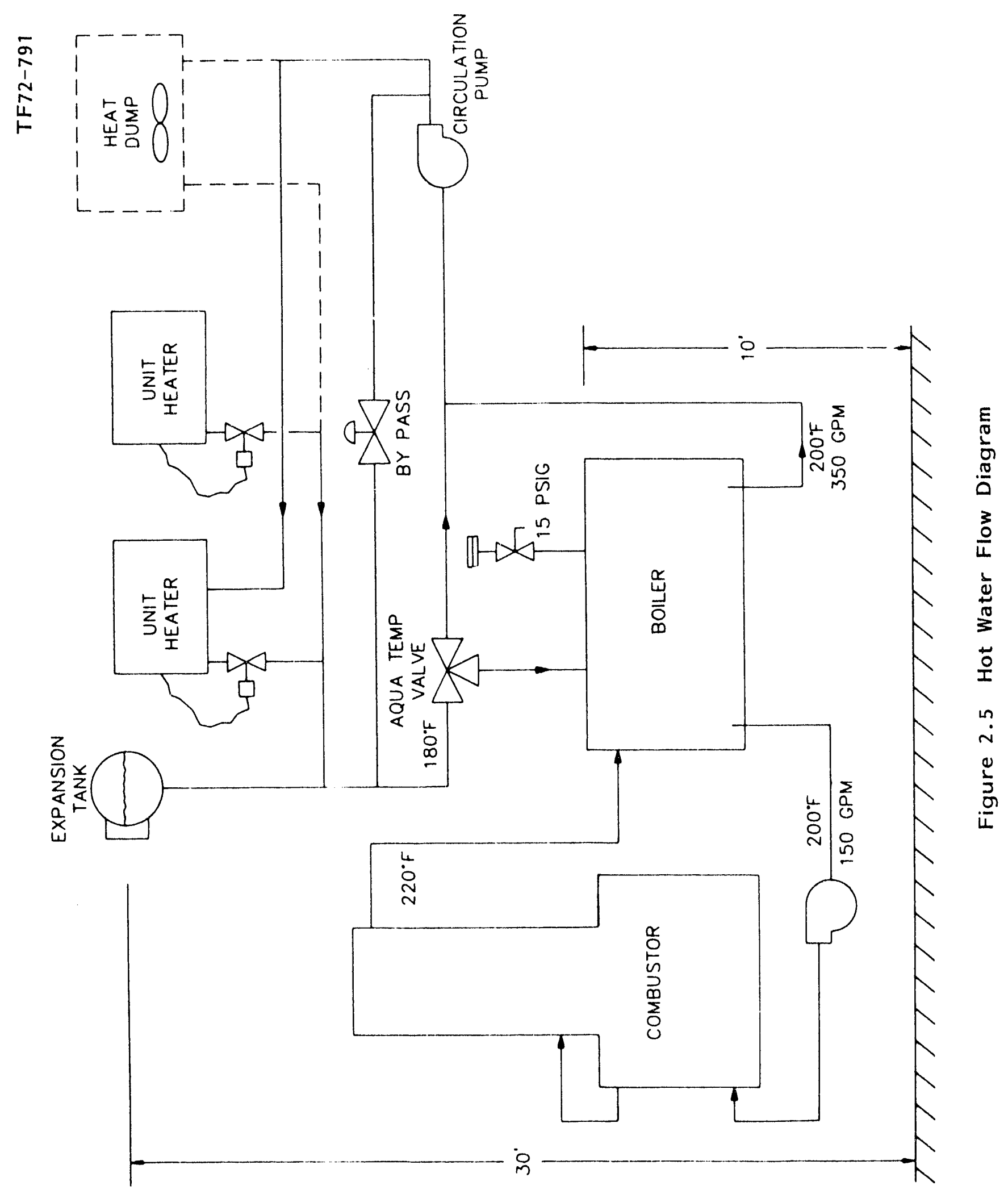




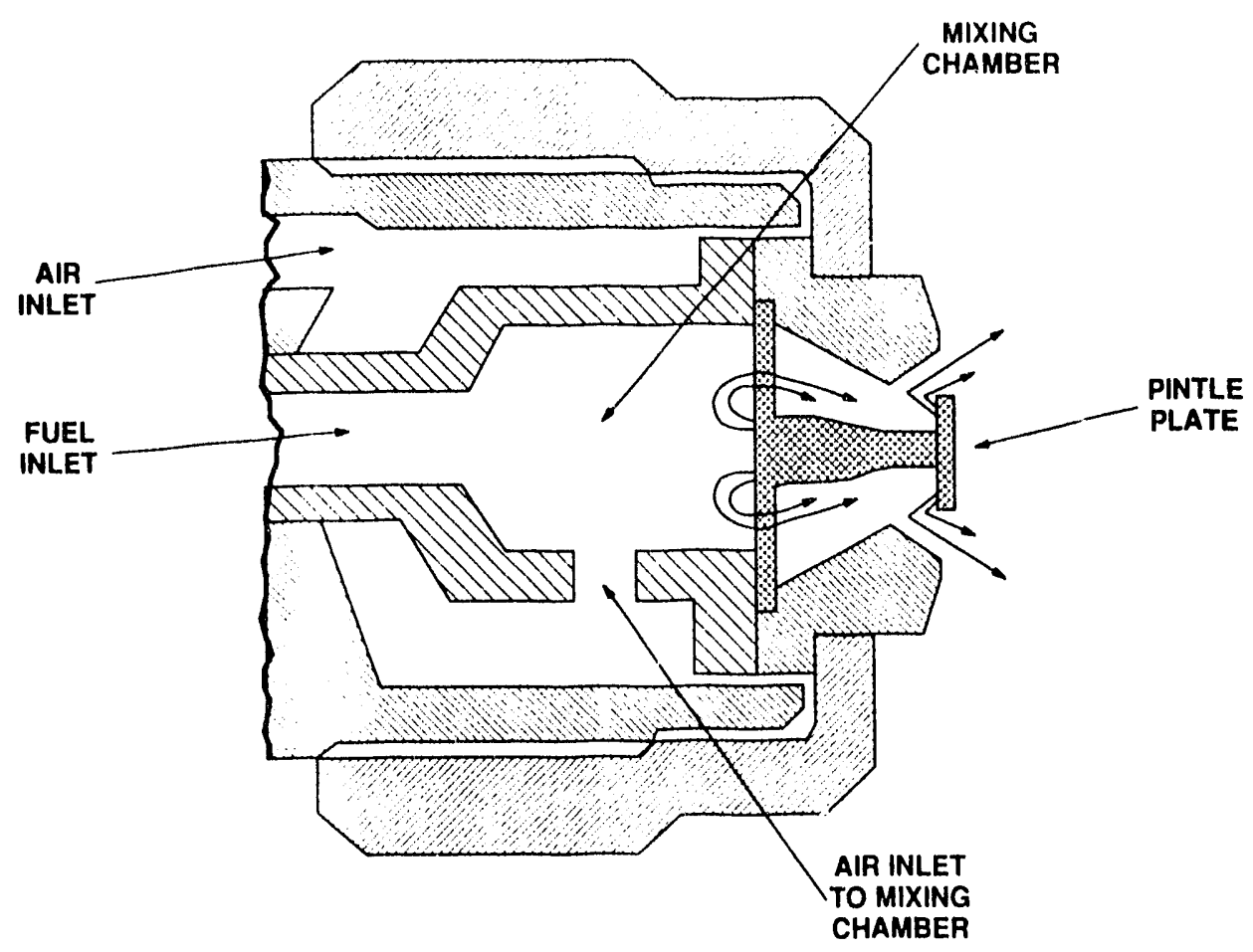

Figure 2.6 Delavan Delta Swirl-Air Atomizing Nozzle

TF77.291

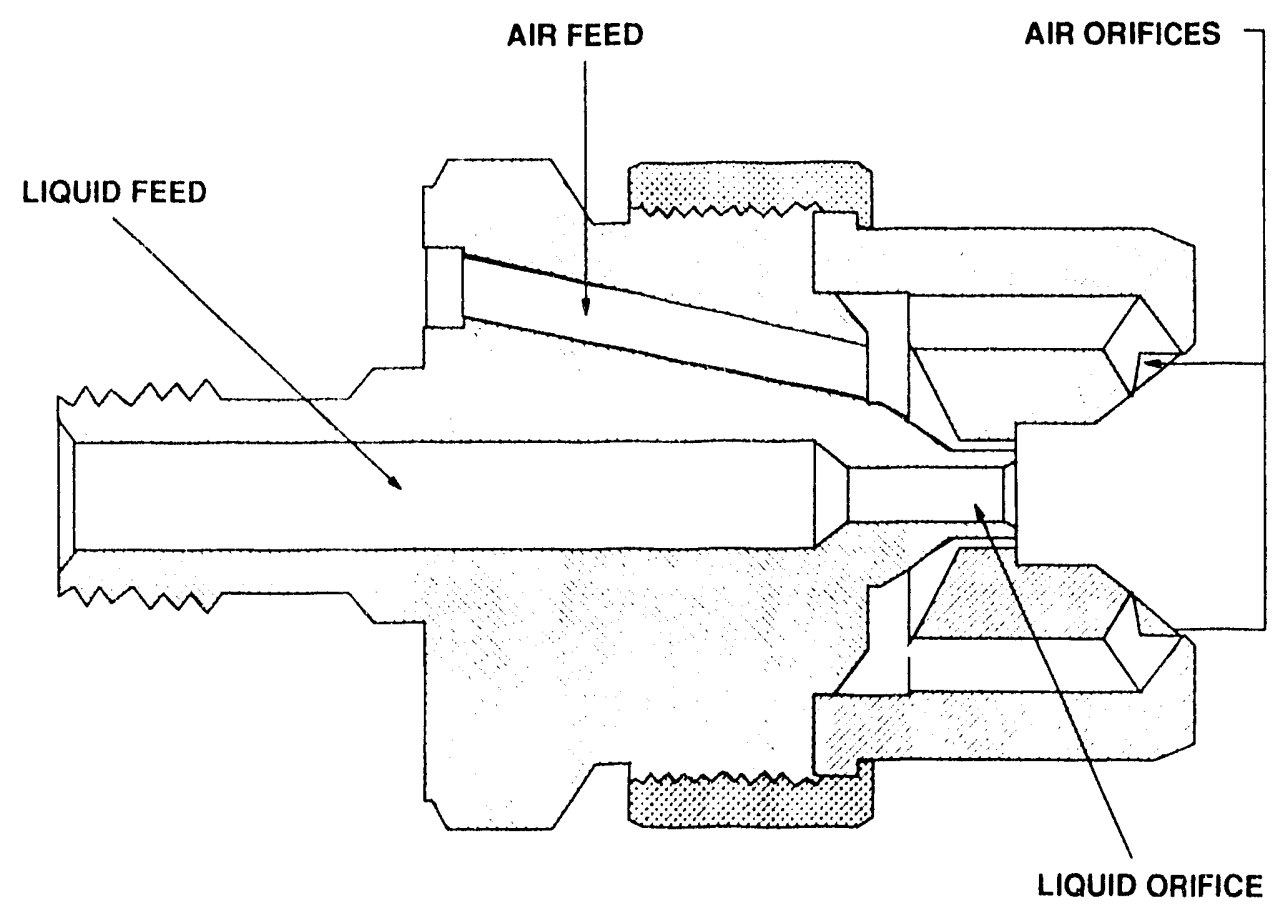

Figure 2.7 Bete XA Series External Mix Flat Fan Nozzle 
变
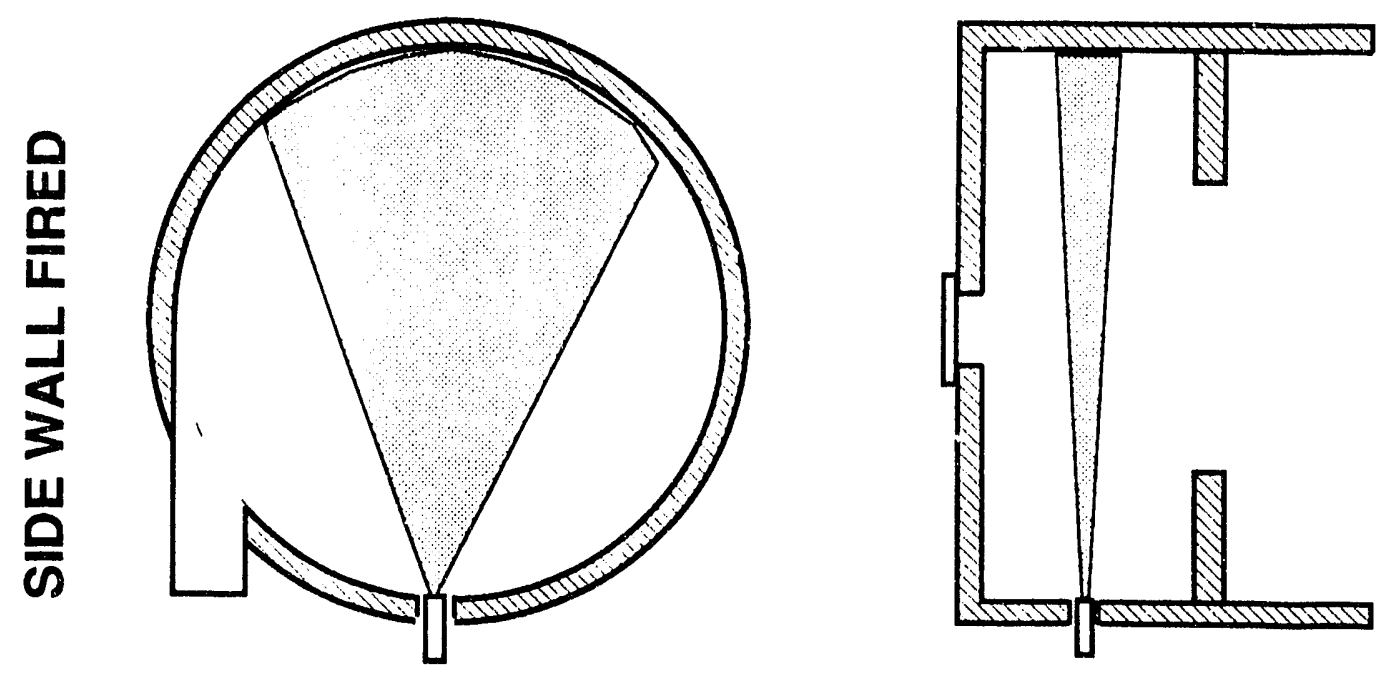

$\frac{n}{2}$
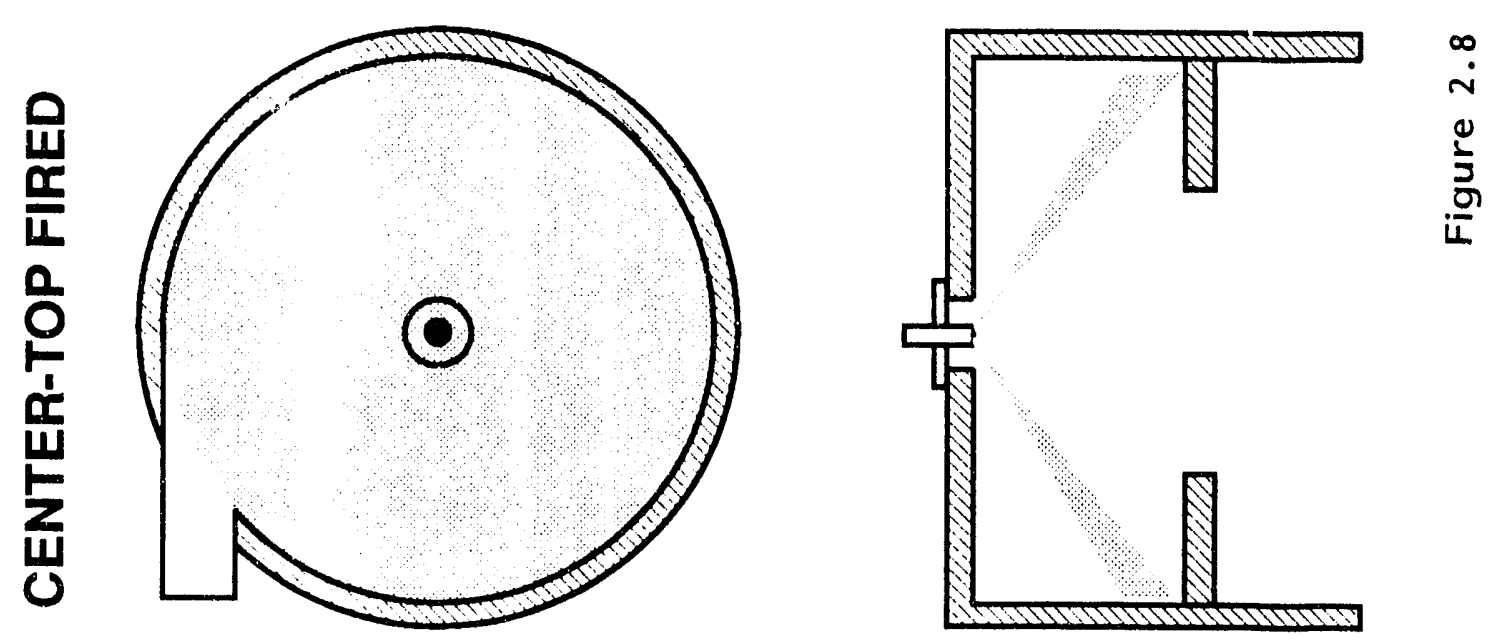


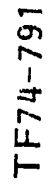

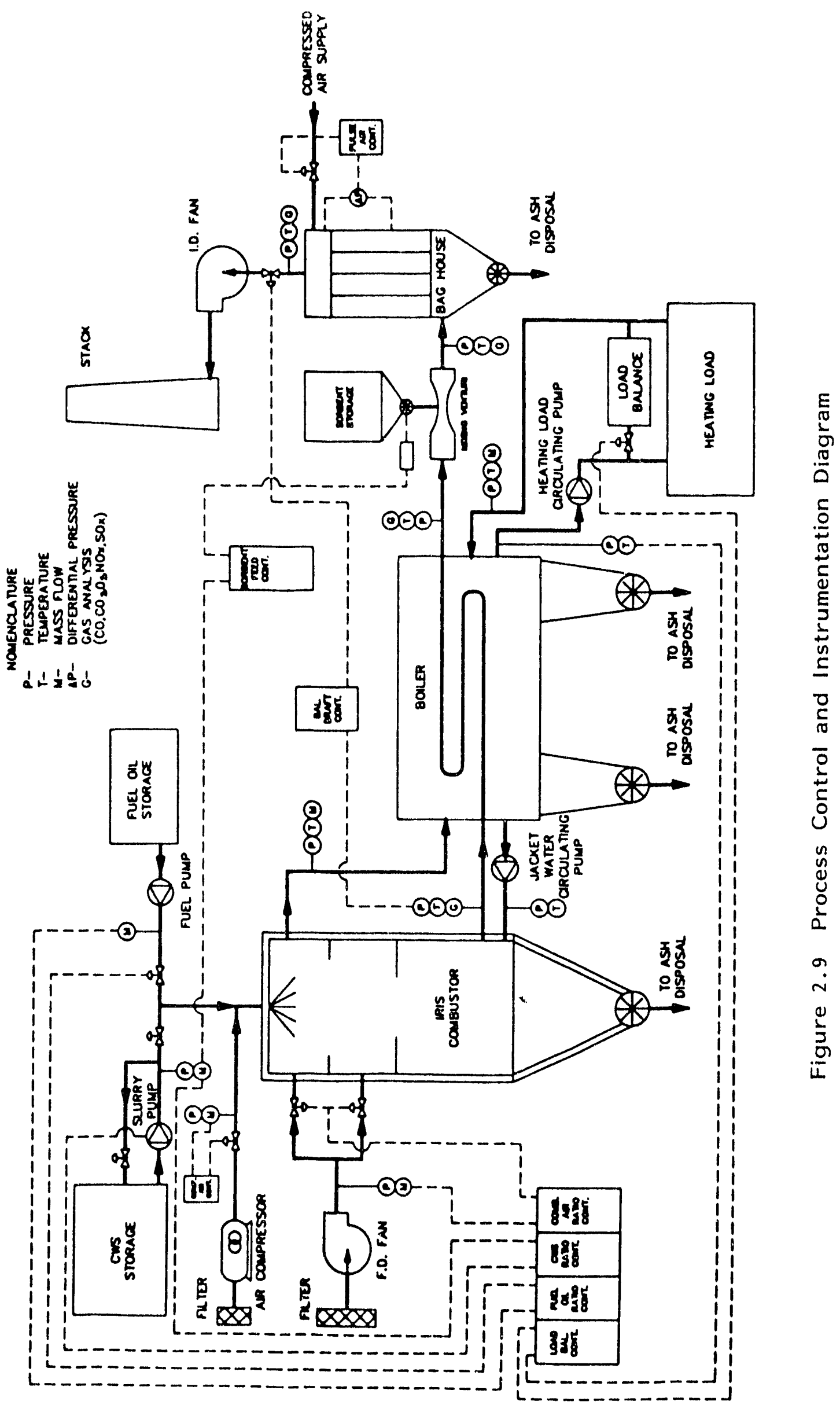


The control system will be arranged so that the combustion system can be operated in either a variable or fixed input mode. In the va.iable input mode, combustor thermal input will be adjusted within the turndown capability of the unit to the heating requirements of the system, as is typically done in space heating systems. In the fixed input mode the combustor input will be fixed and the thermal energy in excess of that required by the space heating system, if any, will be dumped through a load balance radiator or cooling tower. This feature will allow greater flexibility in the test operations and will allow for system operation during periods when space heat is not required.

\subsection{TASK 1.2 - COMPONENT FABRICATION}

\section{Component Design Testing}

Several hot combustion tests were performed to evaluate combustor component design and scale-up parameters. The air inlet of the Tecogen industrialscale combustor was modifled to obtain higher inlet velocities as determined in the combustor scale-up analysis. An adjustable damper was installed so that the inlet slot width could be varied from $3 / 16$ to 3 inch:s.

Initial tests with oll revealed that with top-center firing adequately high wall temperatures could not be achieved in the primary chamber with the higher air inlet velocities. Modifications were made to permit side wall injection of fuel oll adjacent to the air inlet. This change allowed a higher concentration of oll to be burned close to the wall and increased the wall temperature from 800 to $1600^{\circ} \mathrm{F}$.

Slurry injection tests were carried out with both the Delavan Swirl-Air Nozzle and the Bete External Mix Flat Fan Nozzle. With the Delavan nozzle top-center firing, it appeared that the majority of the slurry was projected past the partition and entered the lower section. Modification to the nozzle is required to increase the spray angle, or the length of the primary zone must be increased to get a larger portion of the slurry into the upper section.

The Bete nozzle was used in a side wall injection configuration. With this arrangement slurry could be seen impacting the side wall just beyond the air inlet and being sheared off into droplets by the high-velocity combustion air. It appeared that particle retention in the primary zone was not sufficient, and improvements are necessary to produce a mass of burning particles that provide the heat for slurry droplet vaporization and adequate reaction rates. 


\section{PLANNed ACtivities}

During the next reporting period, detalled design of the combustor and transition chamber will be completed and fabrication of these components will be initlated. Additional combustor testing will be carrled out to evaluate component designs. In particular, cold flow testing will be conducted to assess the particle retention capability of the primary combustor zone configuration. 


\section{SUMMMARY}

During the second quarter of the program, work concentrated on detalled design of the main system components. Detalled design of the combustor. transition chamber, and boller were initiated, and construction of these components will begin during the next reporting period. A hot water distribution system has been configured along with a process control system.

Several component design tests were carried out to evaluate the performance of system components and subsystem arrangements. Atomizers, slurry pumps, ignitors, fuel oil components, etc., were evaluated. 

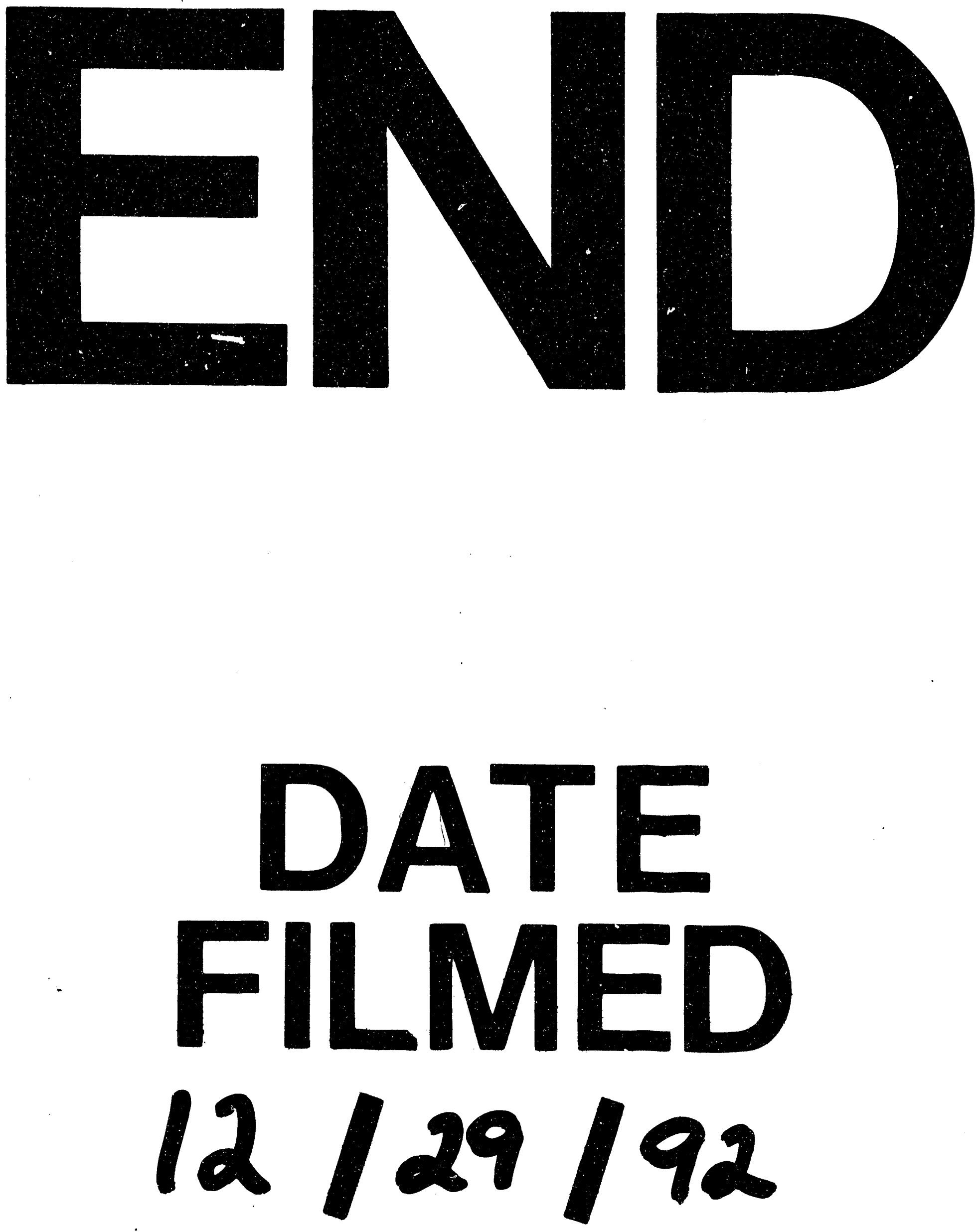

1 
